\title{
A NEW RECORD OF TRACHELIASTES MACULATUS KOLLAR, 1835 (COPEPODA, SIPHONOSTOMATOIDA, LERNAEOPODIDAE) ON COMMON BREAM (ABRAMIS BRAMA (L., 1758)) IN THE NETHERLANDS
}

\author{
BY
}

\author{
PETER D. WALKER ${ }^{1,4}$ ), WOUT ABBINK ${ }^{2}$ ), GERARD VAN DER VELDE ${ }^{1,3}$ ) \\ and SJOERD E. WENDELAAR BONGA ${ }^{1}$ )
}

1) Department of Animal Ecology and Ecophysiology, Institute for Water and Wetland Research, Faculty of Science, Radboud University Nijmegen, Toernooiveld 1, NL-6525 ED Nijmegen,

\section{The Netherlands}

2 ) Department of Organismal Animal Physiology, Institute of Neuroscience, Faculty of Science, Radboud University Nijmegen, Toernooiveld 1, NL-6525 ED Nijmegen, The Netherlands 3 ) National Museum of Natural History "Naturalis", P.O. Box 9517, NL-2300 RA Leiden, The Netherlands

Parasitic crustaceans are currently receiving a more focused and intensive research interest due mainly to the potentially devastating effects these pathogenic organisms can have on aquaculture operations (Walker et al., 2004). However, only recently have researchers begun to pay attention to the effects fish lice can have on wild fish populations and fisheries (Johnson et al., 1996; Jacobson \& Gaard, 1997; Northcott, 1997). Much of this attention is linked to the potential interactions that can occur between wild and farmed fish stocks (De Meeûs et al., 1993), i.e., transfer of parasites from wild fish to farmed fish and/or vice versa. Yet, despite this potential impact, very little attention is paid to parasite populations on wild fish stocks apart from the occasions when they reach proportions that already have a significant, negative impact on fish populations.

Piasecki et al. (2004) stated that copepods belonging to the genus Tracheliastes are the least known of all the freshwater lernaeopodid genera. Furthermore, they state that Tracheliastes maculatus Kollar, 1835 (fig. 1) is the most pathogenic species of the genus.

In this paper we document the first known case of this species, on a population of common bream, Abramis brama (L., 1758) from the river Waal, the main distributary of the river Rhine, in the Netherlands.

T. maculatus is a parasitic copepod belonging to the family Lernaeopodidae. It shows high specificity with respect to its host, being found almost exclusively on

${ }^{4}$ ) e-mail: P.Walker@science.ru.nl 


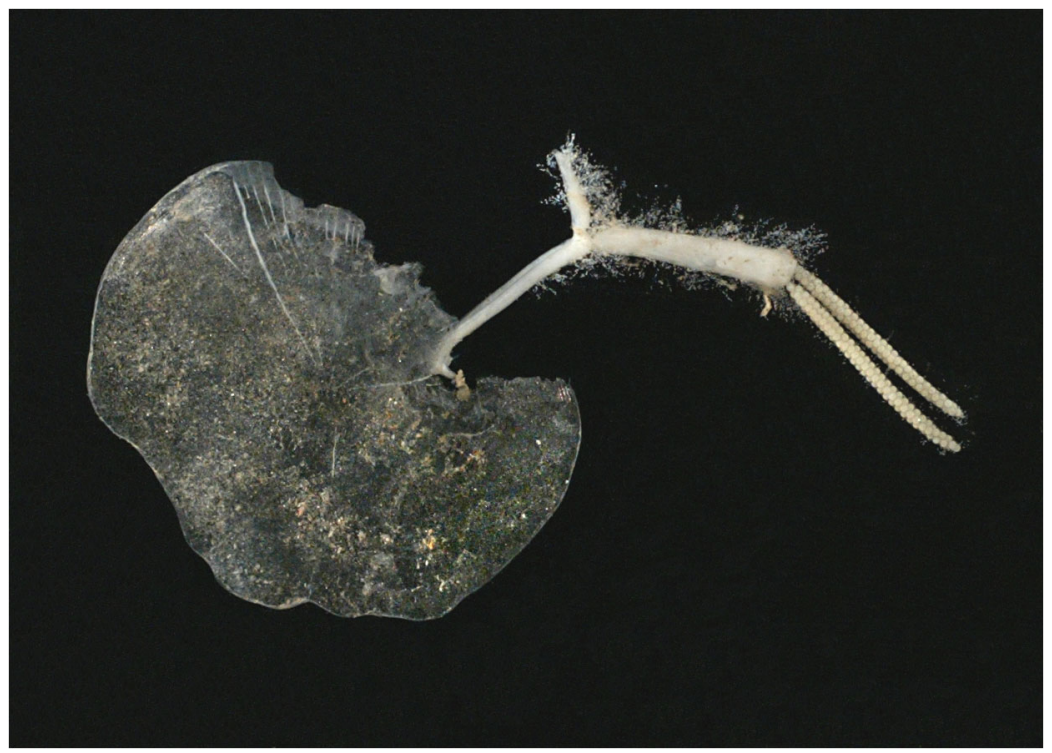

Fig. 1. Micrograph of an adult female Tracheliastes maculatus Kollar, 1835 preserved in $70 \%$ ethanol attached to a scale from an adult common bream, Abramis brama (L., 1758). This specimen has 2 attached egg sacs and filamentous algae can be seen attached to the trunk, cephalothorax, and proximal regions of the maxillary arms. Scale bar $=1 \mathrm{~cm}$.

bream, although it is also reported on other cyprinids including silver bream, Blicca bjoerkna (L., 1758) (cf. Grabda \& Grabda, 1957), roach, Rutilus rutilus (L., 1758) (cf. Romanowsky, 1954), and nase, Chondrostoma nasus (L., 1758) (cf. Piasecki, 1989). The records on roach and nase, however, are rather doubtful records and have never been properly documented.

Adult females (fig. 1) become permanently attached to their hosts' scales by means of a specialized attachment organ known as the bulla. Female parasites can reach lengths exceeding $15 \mathrm{~mm}$ (excluding egg sacs). The life cycle consists of eight stages: egg, pre-moult nauplius, infective copepodid, four chalimus stages, and the adults (Piasecki, 1989).

The pathological effects of this parasite species on its host have been described by some authors (Grabda \& Grabda, 1957; Piasecki, 1991), however, these authors do not describe the effects in much detail. Grabda \& Grabda (1957) concluded from an extensive study that, during mass invasion, T. maculatus can cause serious morbid changes in bream, e.g., local hyperaemia and petechiae (small red spots that do not blanch when pressed upon) around attachment sites of parasites, which can lead to inflammation of the skin. They also stated that the parasites can cause mass loss to fish stocks either directly or indirectly by lowering the vitality of the fish. Similar symptoms are also described by Piasecki et al. (2004). 
The river Waal is a medium-sized river forming part of the Rhine river system. It serves as a main transport route for ships travelling from the commercial port of Rotterdam, through the Netherlands into the German Ruhr region and other parts of Europe. In previous decades the river was heavily polluted, but in recent years the water quality has improved considerably and the result is that some fish species that had apparently disappeared from this system have now returned (Admiraal et al., 1993; Bij de Vaate et al., 2006). The lower Rhine and its delta waters lying in the Netherlands form the so-called bream zone of the river.

Sampling in the river Waal took place during the summer (June-August) of 2005. Fish were caught using standard coarse angling techniques. Upon capture they were restrained and had their eyes covered with a damp cloth. Subsequently the fish were examined for macro-ectoparasites and any specimens observed were removed carefully using forceps and stored in $70 \%$ ethanol for later identification. Parasites were examined using a Leica stereoscope (MZFLIII) and identified using descriptions from Fryer (1982), Kabata (2003), and Boxshall \& Frear (1990).

Only the ectoparasitic crustaceans were recorded and 35 fish (all bream) were examined in total. Common bream were found to harbour two main macroectoparasite species, Argulus foliaceus (L., 1758) and Tracheliastes maculatus, with a prevalence of 60 and $80 \%$, respectively. Fifteen fish harboured both parasite species and 16 were infected with either A. foliaceus or T. maculatus. Only 4 of the 35 fish were not carrying either parasite. Infection intensities were relatively low for A. foliaceus (mean $1.8 \pm 1.7$ s.d. lice per fish, range 0-5). Infection intensities for T. maculatus however, were considerably higher (mean $6.2 \pm 4.8$ s.d. copepods per fish, range 0-19). In addition, fish typically exhibited numerous lesions concurrent with those caused by the above mentioned ectoparasite species (fig. 2). Lesions appeared as reddened areas of the epidermis increasing in colour intensity towards a central point. In some cases, localized swelling, probably caused by infiltration of leukocytes due to an inflammatory response, was also apparent as a small (1-2 mm) raised lump.

To the knowledge of the authors this is the first documented case of T. maculatus from the river Waal and only the second published record of this species' presence in the Netherlands. A previous report detailed T. maculatus as being abundant on common bream in Frisian lakes and of concern due to the red spots it causes (Anonymous, 1982). This report also stated that the parasite was most numerous during summer months, as with our study, and disappeared in November. Previous reports on this parasite species record it in Central Europe from Finland to Austria and from Belgium to central Russia (Kozikowska, 1957), but most reports come from Poland (Grabda \& Grabda, 1957; Piasecki, 1986; Piasecki et al., 2004). The parasite is also known from Britain (Boxshall \& Frear, 1990). 


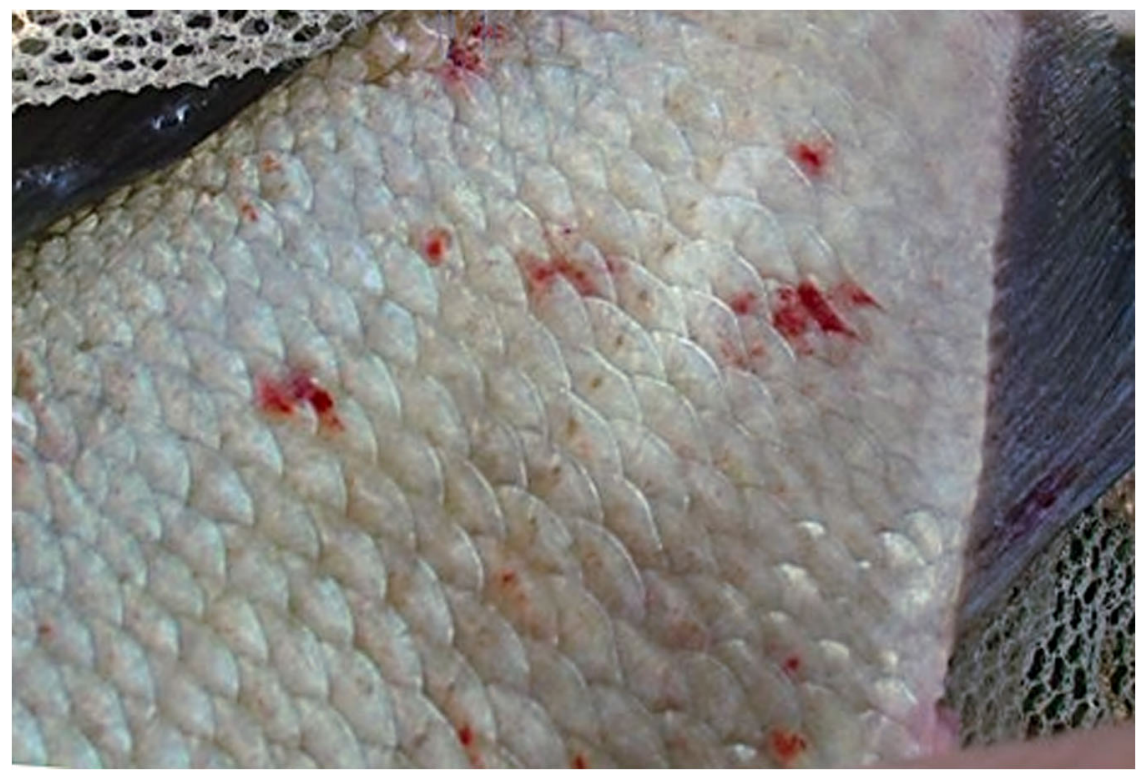

Fig. 2. Red lesions associated with attachment and feeding of Tracheliastes maculatus Kollar, 1835 on the flank of an adult common bream, Abramis brama (L., 1758). Scale bar $=1 \mathrm{~cm}$.

Whilst the occurrence of this parasite in the river Waal is not surprising (it is already believed to be wide spread across much of Europe) the authors feel its presence is worth documenting due to the potential impact this species can have on fish stocks if infection levels become particularly high. The high prevalence and infection intensity observed in this study could be indicative of an infestation sufficient to have a significant deleterious impact on this river systems bream stocks.

This is CWE publication nr. 453.

\section{REFERENCES}

ANONYMOUS, 1982. Project 5-7034 - effect of heated waste water on fish numbers. Visserij, 35 (3-4): 174.

Admiraal, W., G. VAn der Velde, H. Smit \& W. G. Cazemier, 1993. The rivers Rhine and Meuse in the Netherlands: present state and signs of ecological recovery. Hydrobiologia, 265: 97-128.

Boxhall, G. A. \& P. A. Frear, 1990. Tracheliastes maculatus (Kollar, 1836) (Crustacea: Lernaeopodidae) a new species for Britain. Journ. Fish Biol., 37: 489-491.

FRYER, G., 1982. The parasitic Copepoda and Branchiura of British freshwater fishes: a handbook and key. Freshw. biol. Ass. scient. Publ., 46: 1-87.

GRABDA, E. \& J. GRABDA, 1957. Tracheliastosis in the common bream, Abramis brama L. in Lake Jamno. Zool. Polonica, 8: 325-334. 
JACOBSOn, J. A. \& E. GAARD, 1997. Open ocean infection by salmon lice (Lepeophtheirus salmonis): comparison of wild and escaped farmed Atlantic salmon. Journ. mar. Sci., 42: 843849.

Johnson, S. C., R. B. Blaylock, J. Elphick \& K. HyatT, 1996. Disease caused by the salmon louse Lepeophtheirus salmonis (Copepoda: Caligidae) in wild sockeye salmon (Oncorhynchus nerka) stocks of Alberni Inlet, British Columbia. Canadian Journ. Fish. aquat. Sci., 53: 28882897.

Kabata, Z., 2003. Copepods parasitic on fishes. In: J. H. Crothers \& P. J. HAYward (eds.), Synopses of the British Fauna, 47 (revised): 1-274. (FSC Publications, Shrewsbury).

KozIKowsKa, Z., 1957. Skorupiaki pasozytnicze (Crustacea parasitica) Polski, Cześć I. Pasozyty ryb wód ujsciowych Odry. Zool. Polonica, 8: 217-270.

MeEÛs, T. DE, A. Raibaut \& F. Renaud, 1993. Speciation and specificity in parasitic copepods: caligids of the genus Lepeophtheirus, parasites of flatfish in the Mediterranean. In: G. A. Boxshall \& D. Defaye (eds.), Pathogens of wild and farmed fish, sea lice: 143-150. (Ellis Horwood, New York).

NorthсотT, S. J., 1997. An outbreak of freshwater fish lice, Argulus foliaceus L., seriously affecting a Scottish stillwater fishery. Fisheries Management and Ecology, 4: 73-75.

PIASECKI, W., 1986. Description of the male of Tracheliastes maculatus Kollar, 1835 (Siphonostomatoida, Lernaeopodidae). Syllogeus, 58: 584-588.

_ _, 1986. Extrusion of the filamentum frontale in copepodids of Tracheliastes Kollar, 1835 (Siphonostomatoida: Lernaeopodidae). Syllogeus, 58: 589-593.

— - 1989. Life cycle of Tracheliastes Kollar, 1835 (Copepoda, Siphonostomatoida, Lernaeopodidae). Wiadomosci Parazytologiczne, 35: 187-245.

_ - 1991. Tracheliastosis of bream, Abramis brama (L.) in Pierzchalski Lake near Braniewo. Materiały XVI Zjazdu Polskiego Towarzystwa Parazytologicznego; Poznań, 12-13 September 1991: 28. (Polskie Towarzstwo Parazytologiczne, Poznań) [In Polish.]

Piasecki, W., A. E. Goodwin, J. C. Eiras \& B. F. NowaK, 2004. Importance of Copepoda in freshwater aquaculture. Zool. Stud., 43: 193-205.

Romanowsky, A., 1954. Tracheliastes Kollar, 1836 nový parasitický copepod pro územi Č.S.R. Věst. Československá Společnost Zoologická, 18: 1.

VAate, A. BiJ DE, R. BReukel \& G. VAN DER Velde, 2006. Long-term developments in ecological rehabilitation of the main distributaries in the Rhine delta: fish and macroinvertebrates. Hydrobiologia, 565: 229-242.

Walker, P. D., G. Flik \& S. E. WendelaAr Bonga, 2004. The biology of parasites from the genus Argulus and a review of the interactions with its host. In: G. WIEGERTJES \& G. FLIK (eds.), Host-parasite interactions: 107-129. (Garland/BIOS Scientific Publishers, Abingdon).

First received 2 May 2006.

Final version accepted 19 May 2006. 